\title{
Disaster Awareness Insights in Early Children Age Education Based on Gender
}

\author{
$1^{\text {st }}$ Nandhini Hudha Anggarasari \\ Faculty of education \\ University of Muhammadiyah Tasikmalaya \\ Tasikmalaya, Indonesia \\ nandhini.hagrs@umtas.ac.id \\ $4^{\text {th }}$ Setya Wahyuningsih
Universitas Siliwangi
Tasikmalaya, Indonesia
}

\author{
$2^{\text {nd }}$ Fajar Nugraha \\ Faculty of education \\ University of Muhammadiyah Tasikmalaya \\ Tasikmalaya, Indonesia \\ $5^{\text {th }}$ Cucu Arumsari \\ Faculty of education \\ University of Muhammadiyah Tasikmalaya \\ Tasikmalaya, Indonesia
}

\author{
$3^{\text {rd }}$ Muhammad Taufiq \\ Faculty of education \\ University of Muhammadiyah Tasikmalaya \\ Tasikmalaya, Indonesia
}

\begin{abstract}
Disasters that often occur in Indonesia have a serious impact on all communities. Disaster awareness, from mitigation to rehabilitation, is one of the important aspects to reduce the impact of disasters. This awareness needs to be instilled early on in early childhood, but the most important thing that needs to be known is the insight about the disaster in early childhood educators themselves. Early childhood educators can consist of men and women who have different attitudes, roles, responsibilities, functions, rights, and behaviors. This study aims as a basic assessment to find out the different awareness of disaster awareness in early childhood educators based on gender. The method of data analysis was conducted in this study using SPSS version 12.00 program facilities and descriptive data analysis using interviews will be reduced, which are categorized into various aspects, then coupled with the results of an open questionnaire. The analysis technique of the U-Mann Whitney test shows a score of $p>0,05$ which means there is no difference in the awareness of disaster-based awareness of gender.
\end{abstract}

Keywords-Disaster Awareness, Early Children, Education

\section{INTRODUCTION}

Indonesia is one of the countries that often experiences disasters. According to Sutopo Purwo Nugroho, Head of the BNPB Information and Public Relations Data Center, 2016 is a year of disaster. 1,985 disasters occurred, which is the highest record for the past ten years. (Syaiful, 2016). According to RI Law No. 24 of 2007, concerning disaster management, a disaster is an event or series of events that threaten and disrupt people's lives and livelihoods caused by natural and/or human factors that result in fatalities, environmental damage, property losses and psychological impact.

The impact of psychological disasters can occur in all ages, ranging from infants, children, adolescents, adults, to the elderly. The impact of disasters in general is related to health, social life, economy, religious life, and psychology. The psychological impact can be in the form of post traumatic stress, appreciation of experiences during a disaster, reduced social support, lack of optimal ability to adjust to changes that occur, reduced self-esteem owned, to the reduced positive expectations.

The impact of disasters based on gender by data from the Government of India, shows that among the population killed, the number of women and children is too large. In Tamil Nadu, the worst affected state, the number of women killed has tripled in average. In the floods in West Bengal in 2000, more women and children were killed than men. (Pincha, 2008).

The lack of capacity possessed by women makes it a vulnerability. The more vulnerable, the greater the risk of a natural hazard becoming a disaster for any community. Some communities are more vulnerable to disasters than others because of gender inequality.

Based on research by Nastiti et al (2016), several BPBD policies in Sleman Regency are still gender blind because they do not specify men or women, proven by the lack of gender-disaggregated data needs. So it cannot see gender differences in the allocation of roles and resources. PB policy makers are expected to not be gender neutral in implementing PB policies, thereby causing policies to be less gender specific. By adding the word "woman" in PB policies, it does not guarantee the realization of gender equality justice can be realized properly. Women's participation in disaster is not only an object but also an active subject as an agent of change.

Narieswar (2012) made a vulnerability map in Bantul based on gender. The map provides information on gender strength spatially will be very helpful as a guide for decision makers and practitioners of disaster management in disaster mitigation and emergency response. Disaster 
thematic risk maps for strengthening gender roles are intended to encourage the ease of map readers in conducting regional comparisons and identifications and can be utilized to evaluate efforts to increase the capacity of the area if high risk and minimize vulnerability (choice of action). Gender risk maps for disasters are classified into 3 levels of risk; high, medium and low. The risk mapping process is complex and the results are attempted communicatively without removing the characteristics of each of its constituent indicators.

Vulnerability based on gender starts from cultural insights and perspectives in positioning men's roles in disasters, both at the mitigation, emergency response, recovery, rehabilitation and construction stages. Narieswar's research (2012) is one of the studies on mapping that is useful for the rehabilitation and construction process after the Yogyakarta earthquake. At this stage human resources are needed for both women and men, without being influenced by gender stereotypes.

One of the stages of a disaster that needs attention is the awareness of the disaster at the mitigation stage. According to Kousky (2016), disaster mitigation in early childhood is important, because disasters can have an impact on children, such as physical health impacts, mental impacts, and the sustainability of education. The length of time a child can accept a disaster and can rise again to live his life is very dependent on the surrounding environment; family, community, and the environment where he lives. Therefore it is necessary to improve policies on mitigation and coping strategies for children.

Mitigation is not only about socializing disasters or sharing knowledge about disasters, but also training the ability and skills of teachers and educators so that they can apply it when disasters occur. By doing so, at least it can minimize the psychological impact of disasters, because it has been mentally prepared early on. According to OASIS (2015), mitigation in early childhood needs to be well programmed so that the understanding and skills can last longer. The program also needs to be in line with the awareness process for parents, teachers, and the environment where children live.

According to Anggarasari (2017), educators in PAUD have lack knowledge of disasters, so there is a need for socialization or training to convey information about disasters for children properly and optimally.

Awareness process on parents, teachers, and the environment where children live need appropriate and efficient effort. Therefore it is necessary to have an effort to map awareness of gender-based disaster awareness to know and evaluate the potential and vulnerability in dealing with disaster hazards.

\section{A. Disaster}

Disasters are serious disruption to the functioning of a society, which can cause widespread damage to human life in terms of material, economic or environmental and that exceeds the ability of the community concerned to cope with the damages and using the resources. (Paripurno, 2007)

\section{Factors Affecting Psychological Vulnerability}

Not everyone will experience the same symptoms and psychological effects when facing a disaster.

Several factors that can increase or decrease the risk including:

- Severity. The more severe the disaster, the worse the possible impact. In the case of Nazi concentration camps, the Rwandan genocide, Killing Fields in Cambodia, almost everyone who experienced a traumatic event suffered the consequences for a very long time.

- The type of disaster. Disasters that occur due to humans will have more severe impacts than natural disasters. War, terrorism and social unrest have had more psychological damage than the earthquake, tsunami or flood. Disasters due to deliberate humans (burning of shops, rape), will be more damaging than unintentional (workplace accidents, building collapse). Two shop owners whose shops were on fire during the riots in Solo on May 14, 2008, showed different reactions. The shop owner whose shop was burned directly in a mass rampage, showed a stronger ptsd symptom than the shop owner whose shop caught fire in the riots but indirectly (due to strong winds, carrying fire from house to house).

- Gender and age. Women (especially mothers who have toddlers), children ages five to ten, and older people are more vulnerable than others. People with weaker physical endurance will interpret a greater/terrible threat than someone with stronger endurance. In contrast to infants and children under 2 years, although they are still physically weak, their psychological condition is largely determined by parents or adults who are near them because their cognitive ability to recognize danger is still limited. If the adults around them are calm, they will also be relatively calm.

- Personality. People with mature personalities, positive self-concepts and good resilience will be more capable than those who do not have. People who grow up with no confidence, when facing a disaster will also perceive their strengths and their future negatively and pessimistically.

- Availability of networks and social support. The existence of a supportive family, friends, and the community will be able to reduce the possibility of long-term side effects. Communities that are still close and caring for one another will be better able to overcome difficult times than individualist urban societies. Visits and greetings to survivors will speed up their recovery. In this factor, the tradition of festivity of 7 days, 30 days or 100 days after death in the Muslim community in Java or a consolation service for Christians has a big role in recovery. Survivors who lost family members received social support in the presence of relatives and friends.

- Previous experience. Those who have overcome trauma in the past will be better able to cope with the next disaster. 
Psychosocial Activities in Every Post-Disaster Stage has a period each stage is flexible and not rigid, depending on the level of disaster, accessibility and government response. Therefore the program below is more flexible.

- Phase of disaster mitigation according to Anggarasari (2017), namely:Information and maps of disaster-prone areas are available for each type of disaster.

- Socialization to increase public understanding and awareness in dealing with disasters, because they live in disaster prone areas.

- Knowing what needs to be done and avoided, and knowing how to save yourself if a disaster happens, and

- Arrangement and structuring of disaster prone areas to reduce disaster threats.

2. Emergency Response Phase: Post-direct impact

- Providing crisis intervention services for aid workers, for example defusing and debriefing to prevent secondary trauma.

- Providing emotional first aid (emotional first aid), for example various kinds of relaxation techniques and practical therapy.

- Trying to reunite family and community.

- Reviving routine activities for children.

- Providing information, convenience, and practical assistance.

3. Recovery Stage: First month (Rehabilitation)

- Continuing the emergency response phase.

- Educating local professionals, volunteers, and the community regarding the effects of trauma.

- Training additional disaster counselors.

- Providing short-term practical assistance and support to survivors.

- Reviving social activities and community rituals.

4. Final recovery phase: Second month (Rehabilitation)

- Continuing disaster response work.

- Providing community education and training on resilience or resilience.

- Developing a range of services to identify those who still need psychological help.

- Providing "debriefing" and other services for disaster survivors in need.

- Developing school based services and other institution based community services.

5. Reconstruction Phase

- Continuing to provide psychological and debriefing services for humanitarian workers and disaster survivors.

- Continuing the resilience program to anticipate more disasters.

- Maintaining a "hot line" or other means by which survivors can contact the counselor if they need it.

- Providing training for local professionals and volunteers on psychosocial assistance so that they can be independent.
For children, disaster can be very frightening. Their physicality is not as strong as adults and it makes them more vulnerable to the threat of disaster. The main sense of security of children is the adults around them (parents and teachers) and regular schedules. Therefore children are also very affected by the reactions of their parents and other adults. If parents and their teachers react in panic, children will be even more frightened. When they lived in refugee camps and lost their life order, they do not have regular schedule for learning activities and play. It makes children lose control of their lives. Below are some symptoms of stress in post-disaster in children:

- Fear of being separated from parents or adults, always following their parents, fear of strangers, excessive fear of "monsters" or animals

- Sleeping difficulty or refusing to go to sleep

- Compulsive, repetitive play that is part of a disaster experience

- Return to previous behavior, such as bedwetting or thumb sucking

- Easy to cry and scream

- Self-withdrawal, do not want to play with other children

- Fear, including nightmares and fear of certain sounds, sights, or objects related to the disaster

- Aggressive and irritable

- Easily suspicious

- Complaining of headaches, stomach aches or pain

- Problems at school, refusing to go to school and not being able to concentrate

B. Gender

Gender is a cultural concept that refers to the characteristics that distinguish between women and men in terms of biological, behavioral, mentality, and social culture. Men and women are sexually different, so is their behavior and mentality. But its role in society can be aligned with certain limitations.

The definition of gender is defined as a rule or normal behavior related to gender in a community system. Because of that gender is often identified with sex or genital difference. Although these two types of words namely sex and gender have different concepts. Men and women are sexually differentiated based on their genitals. However, gender differences do not guarantee gender differences.

Gender-based disaster management according to Koentjoro, operationally can be defined as the division of work of husband and wife, boys and girls in facing and solving their life problems caused by the earthquake, leading to independent families. Disaster management is inseparable from the attitudes, roles, rights and obligations of men and women in responding to disasters.

The process of managing disasters based on gender can be started from the initial stage of the disaster, namely the mitigation stage, where opportunities to get counseling and training from women and men are often distinguished. Whereas men and women have the same roles, rights and obligations in responding to disasters. 
C. Research Roadmap

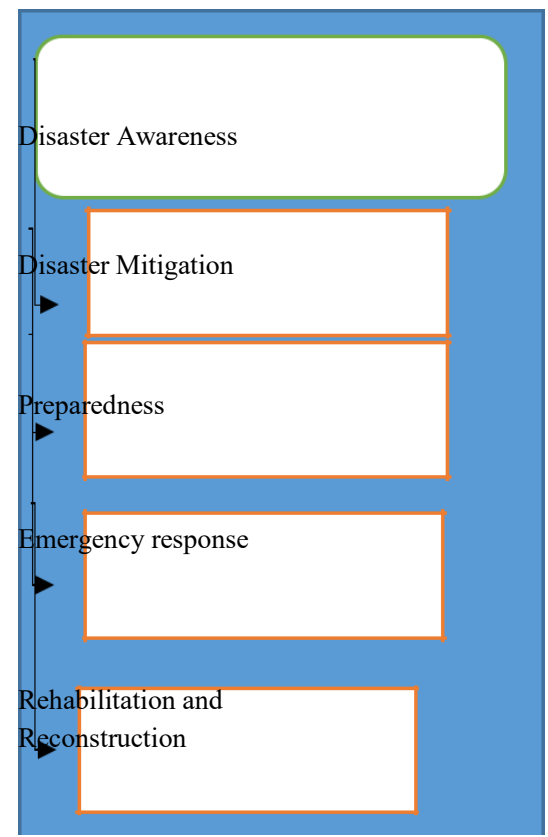

The research roadmap is formulated as follows:

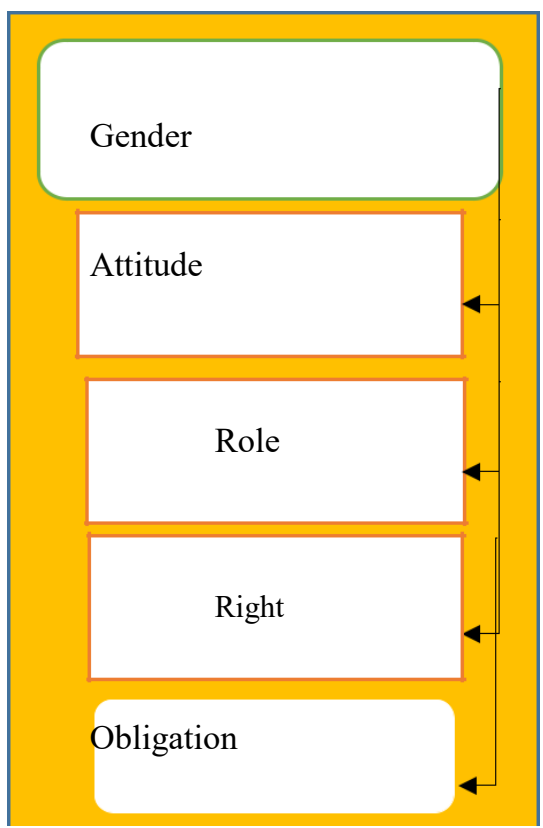

Fig. 1. Research Roadmap

\section{RESEARCH METHOD}

\section{A. Research Stages}

- Making a research measuring instrument

This study uses a measuring instrument in the form of a questionnaire. Questionnaire on disaster awareness and gender aspects. Before being used to retrieve data, this scale will be tested for validity and reliability. The validity and reliability test of the measuring instrument using the variance technique of Alpha Croncbrach with the help of SPSS 12 for Windows. Besides, researchers also used research aids in the form of questionnaires and interview guidelines.

- Planning a research schedule.

- Making research assignments.

- Doing research results.

- Gathering research results.

B. Research Sites

The research location will be conducted in Tasikmalaya Regency. Researchers will randomly research one subdistrict in Tasikmalaya.

TABLE I. THE MEASURED VARIABLES

\begin{tabular}{|l|l|l|}
\hline \multicolumn{1}{|c|}{ Measured Variable } & \multicolumn{2}{c|}{ Measured Variable (Disaster Awareness) } \\
\hline 1. attitude & & \\
\hline 2. role & 1. & Mitigation \\
\hline 3. right & 2. & Emergency response \\
\hline 4. obligation & 3. & Rehabilitation \\
\hline & 4. & Reconstruction \\
\hline
\end{tabular}

\section{Data Collection Technique}

The data collection techniques used was a questionnaire that measures insight into disasters by gender. This research will be analyzed using the analysis technique of the U-Mann Whitney test. To maintain the accuracy and ease of data processing, data calculation techniques are used through the 12 Statistical Software and Service Solution (SPSS) for Windows programs.

Descriptive data analysis by interview will be reduced and categorized into various aspects, then added to the results of an open questionnaire.

\section{RESEARCH RESULTS}

Based on the data obtained through the testing phase of the measuring instrument, the validity test and the reliability test are then performed. Calculations to test the validity and reliability of the scale are carried out with the computer facilities of the Statistical Software and Service Solution (SPSS) 12 program for Windows.

a. The validity of the scale

The validity of the scale and item selection in the study used a different item power index parameter 0.3. Therefore, items less than 0.3 are declared null (Wahana Komputer, 2005). The validity coefficient of a valid or valid item moves from 0.3731 to 0.7453 . 


\section{b. Scale reliability}

The shyness scale reliability test is imposed on items that have met the validity requirements. Reliability testing uses the Alpha Cronbach correlation technique on SPSS 12 for Windows. The reliability test for the shyness scale produces an Alpha coefficient of 0.9008. Thus, the shyness scale can be said to be reliable, so it meets the requirements to be used as a measurement tool for data collection in this study.

\section{c. Hypothesis Test}

The hypothesis was tested using the U-Mann Whitney test analysis, a $p$ score of 0.225 . So the score $p<0.01$. This shows the absence of a very significant difference between men and women.

\section{CONCLUSION}

Based on research conducted, it was found that:

- There is no difference in the awareness of disaster among men and women in Tasikmalaya district.

- The research location is one of the places that lacks exposure to socialization and training on disasters, so that both men and women in general have never received disaster awareness and training.

- There is a need for socialization and training to the community to increase awareness of disaster awareness.

\section{REFERENCES}

[1] Anggarasari. 2017. Terapi Bermain Sebagai Upaya Mitigasi Bencana Tsunami Pada Anak Usia Dini (Paud). Research report (unpulished).

[2] AOSIS. 2015. A Review Of Children's Participation In Disaster Risk Reduction. Diakses tanggal

[3] 31 Januari 2017. Journal of Disaster Risk Studies, Received: 07 July 2015; Accepted: 21 Oct.

[4] 2015; $\quad$ Published: $17 \quad$ Mar. 2016 http://www.jamba.org.za/index.php/jamba/article/view/218/428

[5] Ardianto,Andi. 2013. Implementasi Pendidikan Mitigasi Bencana Gempa Bumi Oleh Guru di SMP Al Islam Kartasura Kabupaten Sukoharjo Tahun Ajaran 2012/2013. A Mini Thesis Publication, University of Muhammadiyah Surakarta.

[6] Kousky, Carolyn. 2016. Impacts of Natural Disasters on Children. Diakses tanggal 31 Janauari

[7] 2017. VOL. $26 /$ NO. $1 /$ SPRING 2016. http://www.futureofchildren.org/publications/docs/spring2016 4.pdf

[8] Koentjoro, Andayani Budi. Dissaster , Gender and Poverty. Artikel Faculty of Psychology Gadjah Mada University Yogyakarta (unpublished)

[9] Mutiah, Diana. 2010. Psikologi Bermain Anak Usia Dini. Jakarta: Kencana Prenada Media Group.

[10] Narieswar, Lalitya,et.al. 2012. Peta Tematik Risiko Bencana Untuk Penguatan Peran Gender Dalam Penanggulangan Bencana. A Geometric Journal Vol. 18, No. 1, Agustus 2012.

[11] Nastiti Nala Nourma, et.al. 2016. Pengarusutamaan Gender Dalam Sistem Penanggulangan Bencana Di Indonesia: Studi Kasus Analisis Implementasi Renstra Bpbd Kabupaten Sleman Di Desa Kepuharjo Kecamatan Cangkringan. Dinamika Global Volume 01 No.1 June 2016.

[12] Paripurno, E.T.2007. Kondisi Geologi Yogyakarta Paska Gempa, Training Materials (unpublished) Center for Disaster Management Study at UPN Veteran: Yogyakarta

[13] Pincha, Chaman. 2008. Penanggulangan Bencana yang Peka Gender. Earthworm Books for Oxfam America and NANBAN Trust. ISBN 81-86945-20-2

[14] Subagia, Wayan, et.al. 2015. Pelatihan Mitigasi Bencana Alam Gempa Bumi Pada Siswa Sekolah Dasar Negeri 1 Pangastulan
Kecamatan Seririt Kabupaten Buleleng Bali. Indonesian Education Journal Vol 4 No 1 April 2015. ISSN : 2303-288X

[15] Syaiful, Anri (2016). BNPB: Ada 1.985 Kejadian, 2016 Tahun Bencana. Diakses Januari 26, 2017. http://regional.liputan6.com/read/2651147/bnpb-ada-1985kejadian-2016-tahun-bencana

[16] Undang-undang RI no 24 tahun 2007, about disaster management

[17] Wahana Komputer. 2005. Pengembangan Analisis Multivariate Dengan SPSS 12. Jakarta: Salemba Infotek Publisher 